Nada Šabec

Univerza v Mariboru

\title{
Language Change in a Contact Situation: The Case of Slovene in North America
}

\begin{abstract}
Avtorica razpravlja o razvoju slovenskega jezika v severnoameriškem izseljenskem okolju. Poudarek je na spremembah, ki se dogajajo na različnih jezikovnih ravninah (predvsem oblikoslovni in skladenjski) pod vplivom jezikovnega stika s pragmatično dominantno angleščino.

The article discusses the development of Slovene in the context of immigration to North America. The emphasis is on various changes observed on different linguistic levels (morphology and syntax in particular) which were brought about primarily through contact with the pragmatically dominant English.
\end{abstract}

\section{Introduction}

Language change has always been one of the most intriguing and fascinating topics of linguistic research. It is usually examined from the diachronic perspective, especially when it is internally motivated. Its synchronic dimensions, however, are just as interesting and it is the purpose of this article to explore the externally motivated language change in the case of Slovene in an immigrant context. While immigrant settings are very specific from the linguistic viewpoint, it is my belief that they are an integral part of the broader language sphere and that it is only by including studies about language use in such linguistic enclaves that we may arrive at a more comprehensive picture of language development in all of its dimensions.

Slovene is a language spoken by approximately 2 million native speakers within Slovenia proper and by a considerable number of speakers outside Slovene borders (according to some estimates as many as one third of all Slovenes live abroad). It seems reasonable to expect that the language variation which applies to the Slovene situation will be greater in an environment where Slovene is in contact with another language and where, in addition, its speakers are geographically separated from Slovenia. Such an environment undoubtedly provides for a less stable and more dynamic development of language and its greater susceptibility to external influences. North America (the United States and Canada) therefore seems an ideal setting to explore the kind of influence that contact with another language (English) exerts on Slovene and to determine any potential language changes brought about by this contact.

\section{Methodology}

\subsection{An Outline of the Bilingual Communities under Investigation}

Data for my study were collected during several time intervals over a longer period of time in the two largest U.S. and Canadian Slovene communities, Cleveland (Ohio) and Toronto (Ontario). The former community has some 50,000 members, 
the latter approximately 10,000. They share a number of features, but also differ in some respects. Only key information about their immigration to North America that is of direct relevance to their linguistic behavior will be presented in this article. The Cleveland Slovenes came to the United States in two major immigration waves: in the period before World War II and after it. The pre-war immigrants who came at the turn of the century and in the first few decades of this century were mostly economic immigrants who came to improve their lives. The majority had had little or no education, no knowledge of English, were illiterate, and spoke mostly just regional dialects of Slovene. Their first contact with English was therefore limited to the borrowing of the most basic lexical items, while on the whole they retained Slovene as their language of communication. Their children acquired education, learned English and became what could be called balanced bilinguals, using Slovene at home and English to communicate with the outside world. In their case borrowing was largely replaced by code switching, an alternate use of two discrete linguistic systems. Code switching is found also with the third generation, but to a much lesser extent, as very few among this generation still speak sufficient Slovene to engage in it. The post-war immigrants settled in Cleveland primarily for political reasons and were much more proficient in both languages. Many had a working knowledge of English. In addition, they were familiar with Standard Slovene and were, contrary to the pre-war immigrants, not limited to the use of their local dialects. They therefore speak both languages and occasionally engage in code switching, depending on various extralinguistic factors ranging from the level of formality of the setting, their relationship with the interlocutors and, to a minor degree, on the topic of conversation. Their children are very similar to the members of the third pre-war generation and only rarely speak Slovene. The comparison of the two groups therefore shows a rapid language shift from Slovene to English, which in the case of the pre-war immigrants ${ }^{1}$ took place over the course of three generations and, in the case of the post-war immigrants, only two.

The Toronto community is much less varied in terms of its generational structure, as only a negligible number of immigrants came in the early 20th century and the vast majority after World War II as political immigrants. For this reason only the post-war immigrants could be considered for the study. The first Slovene-born generation is quite similar to the Cleveland post-war immigrants as far as their proficiency in both languages is concerned. Consequently, they speak relatively fluent Standard Slovene, local dialects, English and also engage in code switching. Their children and younger generations show strong signs of mother tongue attrition. The general impression is that Slovene among those who still speak it is more alive in the Toronto community than in Cleveland, but for the purpose of this article this distinction is not of crucial importance.

\subsection{Data Collection}

Data for the analysis were collected by means of three techniques: tape-recorded interviews, follow-up self-report questionnaires on language use and attitudes,

\footnotetext{
${ }^{1}$ For the sake of economy and convention, the term immigrant(s) is used to refer to all the participants in the study. In fact, only those who emigrated from Europe and settled in America (1st generation) qualify as immigrants, whereas their children are U.S. and Canadian citizens and, strictly speaking, not immigrants.
} 
and participant observation. The subjects chosen for the study belonged to small- or medium-sized social networks (Milroy 1987), which allowed for the observation of linguistic contact among family members, friends and those involved in ethnic organizations. It was expected that interaction among such participants would yield a greater amount of code-switched discourse. The core of my findings is based on the analysis of the excerpts from over 600 hours of tape-recorded conversational interviews $^{2}$ with participants in the study (there were 310 altogether of different ages, educational levels, and of both genders). The observations are occasionally supported by the statistically significant results of the analysis of questionnaire responses to the questions about the respondents' language use and attitudes as well as about their ethnic activities and socialization patterns. Only spoken discourse was used for the analysis as this was the most frequent mode of linguistic communication and because I believed that it was more likely to undergo linguistic change than written discourse.

\section{Findings}

\subsection{Types of Bilingual Discourse}

The data contained two types of bilingual discourse: borrowing and code switching. Borrowing was typically used by members of the first Slovene-born generation of immigrants, especially the pre-war ones in Cleveland, and only occasionally with other participants in the study. The difference was therefore between borrowing as the exclusive means of communication for the former group and its occasional insertion in the otherwise monolingual or code-switched discourse of the latter group. This is understandable considering the fact that the early immigrants knew little or no English. They borrowed primarily those words that helped them fill the lexical gaps caused by the change of lifestyle and new environment and also those that were used to refer to everyday objects and concepts with the greatest frequency. Linguistically, borrowing thus involves taking lexical bases from the donor language and adapting them to the recipient language by adding Slovene suffixes to them. The new words are thus morphologically and partly phonologically adapted to Slovene and are in fact integrated into this modified variety of Slovene. While morphological adaptation is a reliable indication that we are dealing with borrowing, phonological adaptation per se is not a sufficient criterion. In cases where no morphological markings are required, pronunciation might easily mislead us into mistaking a code switch for borrowing simply because of the frequently poor productive competence of speakers in the donor language. Another trap that must be avoided in identifying borrowings are nonce borrowings, one-time idiosyncratic occurrences in the speech of individuals. Borrowings are therefore only those items that meet not only the mentioned grammatical criteria, but also the criterion of social acceptance, i.e., they must be recognized as such by members of the speech community.

\footnotetext{
${ }^{2}$ I termed my interviews conversational to distinguish them from the traditional formal interviews, where the interviewee's role is reduced to merely reacting to the clearly structured questions. Instead I encouraged conversations that were as spontaneous as possible, refrained from interrupting and being judgmental, volunteered my own stories and the like. By encouraging asymmetrical discourse roles and by resorting to peer contexts whenever possible I was hoping to be able to elicit more bilingual data than I would have been otherwise able to do, as well as to eliminate or at least reduce the so-called observer's paradox (Labov 1972: Chapter 8).
} 
The items that are most frequently borrowed from the donor language are nouns, verbs, and past participles used in adjectival function. The following examples illustrate how these borrowings acquire all of the appropriate morphological markings to express various grammatical categories (number, gender, case, aspect).

(1) $t i k c-i$ [from tickets = vstopnice; noun, plural ending $-i]$

(2) lančbaks- $a$ [from lunch-box = posoda za kosilo/malico; noun, feminine suffix $-a]$

(3) $\mathrm{v}$ badišap-o [from bodyshop = mehanična delavnica za popravilo/izdelavo avtomobilskih karoserij; noun, accusative ending -o]

(4) finišan-o [from finished = končano; adjective, neuter gender suffix -o]

(5) $z$-bild-ati [from to build = zgraditi; verbal suffix -ati, perfective prefix $z$-]

The second type of bilingual discourse, code switching, is used by those participants who are proficient in both languages. Especially those who qualify as relatively balanced bilinguals very frequently engage in it, while others resort to it to a much lesser extent. The process involves the alternate use of two languages within the same conversation. There are no morphological adaptations of lexical items and, as a rule, the two linguistic systems remain discrete.

Code switching may occur in either direction, from Slovene to English or vice-versa, depending on the speakers' bilingual competence and their desire to either accommodate their addressees or not. The process most frequently affects the so-called open-class items (nouns, adjectives, adverbs, and less frequently verbs), numerals, and discourse markers. Code switching may occur within a single sentence (intrasententially) or within a longer stretch of discourse involving more than one sentence (intersententially). The former type has been of particular interest to many researchers who have tried to postulate syntactic constraints on code switching. Some went so far as to say that adept bilinguals use exclusively intrasentential code switching (Pfaff 1979, Poplack 1980). My data contradict such views and show that the overwhelming majority of bilinguals, even the most proficient, prefer intersentential code switching. The preference for intersentential code-switches, which is illustrated by example (6) is explained by the presence of some typological disparities between Slovene and English, especially those concerning word order (the fairly rigid SVO word order in English vs. a much more flexible word order in the pro-drop Slovene language).

(6) Na en način je b’lu dobro, na en način ne tako dobro. Ja, sem večno vadil, ker sem drugim pomagal. We call, you know, the growth, there's personal growth that goes on and I just grew and matured and I was very-uh-was a very good experience.

English: On one hand it was good, on the other not so good. Yeah, I constantly practiced by helping the others. We call...

The use of two codes with a relatively low or even non-existing syntactic compatibility in the same sentence would appear to be counterproductive, both in terms of grammatical acceptability and in terms of communicative efficiency, which is why those familiar with the rules of both languages tend to avoid them and opt for intersentential code switching as a superior strategy. Despite this fact, intrasentential 
code switching remains interesting and potentially revealing because the contact between the two languages there is the closest and the most direct.

Both in borrowing and in code switching we see clear signs of cross-linguistic influences. In borrowing, only lexical features of Slovene are replaced by English ones, while the structural ones remain intact. In code switching the process is much more complex and while the two languages remain discrete, there are nevertheless certain convergent tendencies, i.e., the adoption of lexical and structural features from one language into another. There is no doubt, however, that the stronger and the pragmatically dominant of the two in this language pair is English (Matras 1998: 285-286), and the weaker Slovene. The process is therefore fairly one-sided and the pressure on Slovene extremely strong. English is not only superior in terms of the numerical strength of its speakers, but is also associated with prestige, economic, political, and cultural power. Slovene on the other hand is limited to partial use among family members, friends and relatives.

\subsection{Slovene-English Language Contact}

The question that interests us concerns the degree to which Slovene has been affected by language contact. Has the intensity of this contact resulted in any systematic changes in the grammatical structure of Slovene spoken in this environment? Which linguistic levels have been most affected, i.e., are there levels of language that are naturally more susceptible to change in contact situations than others? How profound or indeed stable are any potential contact-induced changes in view of the Matrix Language Frame Model, which has recently been proposed by Myers-Scotton $(1993,1996)$ and explored by a number of other researchers (Matras 1998, Fuller 1996, Savić 1995)? Is the variety of Slovene spoken in this specific environment still Slovene?

In order to answer these questions we need to take a closer look at the data, both at the Slovene elements in the code-switched sentences and at monolingual stretches of Slovene discourse which are equally vulnerable to English influence.

The first area that attracts our attention is morphology with its either apparent random use of inflections or, more frequently, the complete lack of inflectional endings.

(7) And my cousin ima dveh otrok. [genitive instead of accusative]

English: And my cousin has two children.

Standard Slovene: In moj(a) sestrična/bratranec ima $d v a$ otroka.

(8) On je pripeljal me $\mathrm{z}$ veliko avto, s station wagon it was, I think. [feminine instead of masculine]

English: He drove me in a big car, station wagon it was, I think.

Standard Slovene: Pripeljal me je z velikim avtom, mislim, da je bil kombi.

(9) Oh, sem ga spoznala na gredžuejšn dens. [borrowing ${ }^{3}$ from graduation dance; nominative instead of locative]

\footnotetext{
${ }^{3}$ Some examples contain code switches, some borrowings, some both.
} 
English: Oh, I met him at the graduation dance.

Standard Slovene: O, sem ga spoznala na maturantskem plesu.

(10) No, le daj tud' sestr'ca malo potica. [nominative instead of dative and genitive]

English: Come on, let your little sister have some potica, ${ }^{4}$ too.

Standard Slovene: No, le daj tudi sestrici malo potice.

(11) Je bil doma s stari starši all the time. [nominative instead of instrumental]

English: He was home with his grandparents all the time.

Standard Slovene: Ves čas je bil doma s starimi starši.

(12) Oni so šli vsi v šolo brez znat' angleščina. [nominative instead of accusative]

English: They went to school without speaking any English.

Standard Slovene: Vsi so šli v šolo, ne da bi znali angleščino.

A similar lack of agreement is found not only in nouns, but also in adjectives, pronouns, numerals, and other determiners.

(13) To je tista slika, ki si me vid'la z moje štir grandson. [nominative instead of instrumental]

English: This is the picture in which you saw me with my four grandsons.

Standard Slovene: To je slika, na kateri si me videla $z$ mojimi štirimi vnuki.

It seems that the complex system of case endings and other agreement markers is too difficult for the speakers to handle, which is why they opt either for random use or, more frequently and more radically, for the predominant use of the nominative case resulting in the simplification of forms and paradigm leveling. A plausible explanation for this kind of change lies in the universal tendencies for simplification on the one hand and the impact of English morphological patterns such as null case markers on the other.

One particular case, the merger of the accusative and the nominative case, is of special interest as it raises the question of the role of case marking to express subject and object status. In addition the chosen example shows the leveling of the animate/inanimate masculine paradigm.

(14) See, fantek se je zgubil in John je iskal fantek. [nominative instead of accusative]

English: The little boy got lost and John was looking for the little boy.

Standard Slovene: Fantek se je izgubil in John je iskal fantka.

\footnotetext{
${ }^{4}$ The name potica for a typical Slovene pastry is often used by Slovenes in North America even when the rest of their discourse is entirely English. In this sense the term could be regarded as an example of Slovene borrowing into English.
} 
While the subject/object status and consequently the meaning of the sentence in this particular case can be deciphered from the context, it is clear that the decreasing variation in inflectional morphology makes for an increasingly opaque expression and may lead to potential breakdown in communications. English solves such problems by relying on a fairly rigid SVO word order, which is why we need to examine our data from the syntactic viewpoint to see whether Slovene has in any way adjusted to the English model in this respect.

A close examination of the data indeed yields examples that could be interpreted as strongly English-influenced. The word order which is much more flexible in Slovene is gradually losing its variability and becoming more like SVO.

(15) Je b'lo no way za mene to narediti.

English: There was no way for me to do it.

Standard Slovene: Ni bilo načina, da bi to naredila.

(16) In je noben, ki zna še govoriti po domače.

English: And there's nobody who can speak our language anymore.

Standard Slovene: In ni nobenega, ki še zna govoriti po domače.

(17) Veš, jaz sem bila tako vesela te videt' tu pri nas.

English: You know, I was so happy to see you here with us.

Standard Slovene: Veš, sem bila tako vesela, da sem te videla tu pri nas.

There are other signs of English impact. The most salient and frequent one is the excessive use of overt subject and object pronouns in cases where this is not pragmatically and semantically warranted. Slovene is a pro-drop language and only uses such form for emphasis, topicalization and similar purposes. English-influenced Slovene, however, uses it most of the time, thus gradually adopting English word order rules.

(18) See, pa ona je nosila take like-uh-high-heel šuhe, ${ }^{5}$ high-heel čevlje, you know.

English: See, she wore these like-uh-high-heel shoes, high-heel shoes, you know.

Standard Slovene: Vidiš, pa $\varnothing$ je nosila čevlje s takimi visokimi petami.

A noun used as a premodifier in a NP

(19) Jaz sem kupila chicken wings, čiken peruti.

English: I bought chicken wings.

Standard Slovene: Sem kupila piščančje perutnice.

Possession expressed in an English-like manner resembling Saxon genitive

(20) Well, ni b'lo tako težko, ker me je srečala na airport moja grandson žena.

${ }^{5} \check{S} u h e$ is an archaic dialectal form of German origin for the Standard Slovene čevlji. It is frequently used by older immigrants. 
English: Well, its wasn't that difficult because my grandson's wife met me at the airport.

Standard Slovene: No, ni bilo tako težko, ker me je na letališču čakala vnukova žena/žena mojega vnuka.

Incorrect prepositions or their omission

(21) Ja, pa ga je čakala $z a$ cela leta takrat, you know.

English: Yeah, she waited for him for years then, you know.

Standard Slovene: Ja, pa ga je čakala $\varnothing$ cela leta takrat, veš.

(22) Moram iti, ko imam $z a$ dve ura dentist appointment.

English: I have to leave because I have a dentist appointment at two o'clock. Standard Slovene: Moram iti, ker sem $o b$ dveh naročena pri zobozdravniku.

(23) On je bolj reven $\varnothing$ matematiki.

English: He is rather poor in mathematics.

Standard Slovene: Je bolj slab pri/v matematiki.

Confusion between possessive and reflexive possessive pronouns

(24) Pa sem imela moja sestra za company in me ni skrbelo.

English: My sister kept me company, so I didn’t worry.

Standard Slovene: Za družbo sem imela svojo sestro, zato me ni skrbelo.

(25) Samo za svojo familijo je b'lo hudo.

English: It was hard for $m y$ family, though.

Standard Slovene: Samo za mojo družino je bilo hudo.

Use of cardinal instead of ordinal numerals

(26) Moj mož je bil tud' v world vojska ena.

English: My husband was also in World War $I$.

Standard Slovene: Moj mož je bil tudi v prvi svetovni vojni.

Incorrect placement of clitic pronouns

(27) Sem se tako smejala $j i$.

English: She made me laugh so much.

Standard Slovene: Sem se $j i$ tako smejala.

Redundant use of the adverb tam on the analogy of the English expletive there.

(28) Tam so b’li eni res prav čudni ljudje tam.

English: There were some really strange people there.

Standard Slovene: Tam so bili eni prav čudni ljudje $\varnothing$. / Ø Eni prav čudni ljudje so bili tam. 
An alternative explanation for this kind of usage may be the speakers' reinterpretation of tam as both an expletive and a spatial adverbial.

Especially interesting is the case of verb morphology, where the distinctions between the perfective and imperfective aspect, transitive and intransitive, passive and active voice, and reflexive and non-reflexive forms are becoming increasingly blurred, and tenses are sometimes used according to English rules.

Perfective instead of imperfective

(29) On je dolgo časa poskusil to narediti, pa ni uspel.

English: He was trying to do it for a long time, but failed.

Standard Slovene: Dolgo časa je skušal to narediti, pa ni uspel.

Transitive instead of intransitive

(30) Vprašanje so poskušali odgovoriti, pa niso mogli.

English: They tried to answer the question, but couldn't.

Standard Slovene: Skušali so odgovoriti na vprašanje, pa niso mogli.

Passive instead of active

(31) Ko sem b’la še majhna punčka, nisem b’la nikoli verjeta, ker so rekli, da lažem.

English: When I was a little girl, I was never believed because they said I was lying.

Standard Slovene: Ko sem bila še majhna punčka, mi niso nikoli verjeli, ker so rekli, da lažem.

Omission of reflexive pronouns

(32) In otrok $\varnothing$ boji, you know.

English: And the child is afraid, you know.

Standard Slovene: In otrok se boji, veš.

Observation of English sequence-of-tenses rules

(33) $\mathrm{Pa}$ sem jo vprašala, če me je poznala, pa me ni.

English: I asked her if she knew me, but she didn't.

Standard Slovene: Pa sem jo vprašala, če me pozna, pa me ni.

Even though for each of the chosen examples we could find counterexamples with more Slovene-like word order, a certain preference for the English word order can nevertheless be detected in the speech of many participants.

All in all, it seems that the English influence on Slovene is strongest in the area of morphology and syntax. Other areas of Slovene, however, are also susceptible to English influence. This is seen in pronunciation, which is in the case of all but the most recent Slovene-born immigrants, heavily marked by English sound features (e.g., aspirated $/ \mathrm{p} /, / \mathrm{t} / \mathrm{h} / \mathrm{k} /$; velarized instead of clear alveolar $/ 1 /$; retroflex $/ \mathrm{r} / \mathrm{in}$ stead of the alveolar tap $/ \mathrm{r} /$; vowel quality). It is also found in pragmatics and 
semantics. Extensions, generalizations and other changes of lexical meaning (e.g., the use of the word družina 'family' to refer to relatives and just to the nuclear family) and calques (e.g., vzeti slike 'to take pictures' instead of fotografirati; imeti dober čas 'to have a good time' instead of zabavati se; vzeti tuš 'to take a shower' instead of tuširati se) are good examples of the former and the increasingly blurred distinction between formal and informal varieties (e.g., the erosion of the appropriate use of $\mathrm{T}$ and $\mathrm{V}$ personal pronouns in terms of address) are telling examples of that.

Such changes naturally bring us to the question of a matrix language in the sentences presented. The impression that they are at times formed on the analogy of English sentences rather than by the adherence to the rules of Slovene is underscored by the presence of almost exclusively English discourse markers (oh, well, and, but, or, so, because, now, then, I mean, you know, like...). We should exercise caution, however, before jumping to such quick conclusions. For one thing, discourse markers are a very specific group of unbound elements that are primarily used to mark boundaries of continuous discourse and to bracket units or speech (Schiffrin 1987: 31), but are at the same time syntactically detachable and can be inserted in a sentence without any special adjustment to other constituents. While the extremely high frequency of their occurrence is thus no doubt a reflection of the predominantly English environment, their presence alone is limited to their communicative and interactional function and has no significant effect on the grammatical structure of Slovene.

What about the other changes? Are they more significant and what are their implications? The already mentioned Matrix Language Frame Model distinguishes between system and content morphemes (Myers-Scotton 1993: 99-101). It assumes that the morpho-syntactic frame of a code-switched sentence is set by the matrix language (ML), while the other language, the so-called embedded language (EL) is a minor contributor and provides content morphemes in mixed constituents. While for the early immigrants ML is clearly their mother tongue and the host language is EL, later stages may bring about the so-called ML turnover, whereby the pragmatically dominant host language begins to provide system morphemes, thus becoming the new ML and the previous ML is reduced to the level of EL. In the case of Slovene-English language contact the first stage of the process certainly applies. Borrowing is a perfect example of Slovene providing system morphemes and English acting as EL. Further development, however, is more problematic. We are faced with an intermediate stage, where it is very difficult, if not impossible, to determine ML for code-switched utterances with any consistency. Regardless of the very strong influence of English, the utterances are combinations of features from both languages and the ratio between the two shows an extremely high degree of variation with various speakers depending on their bilingual competence and other extralinguistic factors. There is certainly no justification for claiming that ML in the speech of Slovenes in the United States and Canada has become English. While Slovene in this setting has no doubt undergone a strong English influence, it has not adopted lexical and structural features of English to a sufficient degree to meet the criterion of a turnover. At best it is at an intermediate stage with the composite ML made up of both languages. Because of the very unstable nature of this particular bilingual situation it is difficult to say whether or not an intermediate stage could ever have 
progressed to the final stage of an actual turnover. In a more stable and long-lasting bilingual setting the outcome could go either way, in reality the process has been interrupted by a fairly radical and rapid language shift from Slovene to English. This is supported by the questionnaire responses, where the overwhelming majority of the respondents report a partial or even complete language shift from the time when their household language used to be Slovene.

The instability of the bilingual setting coupled with certain typological differences between Slovene and English accounts for the difficulty in postulating strictly syntactic constraints on code switching. With the exception of the so-called freemorpheme constraint and a very limited number of local constraints such as the one relating to preposition stranding (Šabec 1995: 191-210), all the other constraints for different language pairs studied (the structural integrity/equivalence constraint, the size-of-constituent constraint, the government constraint, the asymmetrical-directionality-of-code-switching constraint, the dual-structure constraint, the triggering constraint) fail the test and have no universal validity (Šabec 1995: 194-210). In my view, the syntactic constraints approach is simply too narrow to reflect the socio-psychological reality of bilinguals' linguistic behavior, hence the numerous counterexamples to the mentioned constraints in my data. In order to capture the more universal character of code switching, we need to go further and look into the semantic, pragmatic and communicative dimensions of the phenomenon (Šabec 1995: 250-257). It is the criterion of coherence and comprehensibility of discourse that matters and if sentences containing code switches violate syntactic rules of one or the other language, but still remain intelligible, we have to assume that these violations are of minor importance. The extent to which code switching is acceptable for communication probably also has to do with the cognitive and processing abilities of interlocutors and with their tendency to produce still intelligible utterances. In addition to the impact of the predominantly English-speaking environment, the adjustment of Slovene toward more English-like structures may be triggered by a number of factors (the proximity of constituents, lexical collocations, lexical gaps, cognate items, associations, even the so-called performance errors where the speakers do not have sufficient time to plan and process the elements that make up the sentence, and make corrections as they go along). In either case, though, such changes are too unstable and too short-lived to allow for the postulation of a new matrix language.

\section{Conclusion}

The analysis reveals a number of changes in Slovene spoken in North America. Changes involving substitutions of English lexical items for Slovene ones are naturally expected, as any language that comes into contact with another language is bound to be susceptible to its influence. More intriguing are other changes that have to do with various levels of linguistic structure, morphology and syntax in particular. The regularization, simplification and/or even deletion of the Slovene inflectional system on the one hand and a gradual adoption of English-like word order patterns, point to a considerable degree of convergence of Slovene in the direction of English. While it is possible that such changes are in part due to the universal tendencies toward simplification, they are no doubt primarily motivated by the intensity of the language contact with English. The patterns of the observed changes make it 
tempting to postulate a separate grammar for this particular linguistic variant of Slovene. The very temporary nature of these changes and the extremely high degree of their variation on the other hand effectively preclude such an interpretation.

There is no doubt, however, that this kind of Slovene constitutes a distinct, contact variety of Slovene. It differs from non-English-influenced Slovene in a number of features and could easily be termed a special dialect of Slovene, perhaps North American Slovene. As such it deserves our special attention in that our study of the very diverse and at times difficult-to-define forces shaping it may provide invaluable insights into the mechanisms of linguistic change, while at the same time contributing to a more complete understanding of the linguistic development of all the variants that make up Slovene.

\section{References}

Fuller, M. J. 1996. When cultural maintenance means linguistic convergence: Pennsylvania German evidence for the Matrix Language Turnover hypothesis. Language in Society 25: 493-514.

Labov, W. 1972. Sociolinguistic Patterns. Philadelphia: University of Pennsylvania Press.

Matras, Y. 1998. Utterance modifiers and universals of grammatical borrowing. Linguistics 36/2: 281-331.

Myers-Scotton, C. 1993. Duelling Languages. Oxford and New York: Oxford University Press.

- -. 1996. One way to dusty death: The matrix language turnover hypothesis. In L. Grenoble and L. Whaley (eds.) Language Loss and Community Response. Cambridge and New York: Cambridge University Press.

Milroy, L. 1987. Observing and Analyzing Natural Language. Oxford: Blackwell.

Pfaff, C. 1979. Constraints on language mixing: intrasentential code-switching and borrowing in Spanish English. Language 55: 291-318.

Poplack, S. 1980. Sometimes I'll start a sentence in Spanish y termino en español: toward a typology of code-switching. Linguistics 18: 581-618.

Savić, J. M. 1995. Structural convergence and language change: evidence from Serbian-English code-switching. Language in Society 24: 475-492.

Schiffrin, D. 1987. Discourse Markers. Cambridge: Cambridge University Press.

Šabec, N. 1995. Half pa pu: The Language of Slovene Americans. Ljubljana: SKUC, Studia humanitatis.

- -. 1996. Slovenščina v diaspori: primer ameriških Slovencev. In A. Vidovič-Muha (ed.) Jezik in čas (= Razprave Filozofske fakultete). Ljubljana: Znanstveni inštitut Filozofske fakultete: 107-123.

- -. 1997. Slovene-English language contact in the USA. International Journal of the Sociology of Language 124: Sociolinguistics of Slovene (M. L. Greenberg, ed.): $129-183$. 
Van Tassel, D., and Grabowski, J. J. (eds.) 1987. The Encyclopedia of Cleveland History. Bloomington, Indianapolis: Indiana University Press in association with the Case Western Reserve University.

Prispelo avgusta 1998, sprejeto januarja 1999

Received August 1998, accepted January 1999

\section{Jezikovna sprememba v stiku: slovenščina v Severni Ameriki}

Avtorica opisuje jezikovno stanje med izseljenci slovenskega rodu v ZDA in Kanadi. Zaradi geografske ločenosti od Slovenije, še zlasti pa zaradi izredno močnega vpliva pragmatično dominantnega angleškega jezika, doživlja slovenščina $\mathrm{v}$ tem okolju zelo specifičen razvoj.

Analizira podatke, zbrane $\mathrm{v}$ empirični raziskavi (posnetke intervjujev $\mathrm{z}$ informanti), da bi ugotovila morebitne spremembe, ki so nastale $\mathrm{v}$ jeziku kot posledica stika $\mathrm{z}$ angleščino. Te srečamo $\mathrm{v}$ vseh zvrsteh dvojezičnega diskurza (sposojanje, kodno preklapljanje, enojezični slovenski deli diskurza) in na različnih jezikovnih ravninah od glasoslovja do pomenoslovja in pragmatike. Najizraziteje se angleški vpliv kaže v oblikoslovju, kjer prihaja do poenostavljanja, posploševanja in opuščanja slovenskih sklanjatvenih vzorcev, in v skladnji, kjer postaja besedni vrstni red vedno bolj podoben angleškemu.

Na povedni ravni je za prikazane strukture značilen kombinirani matrični ali osnovni jezik, zaznamovan s tipičnimi lastnostmi iz obeh jezikov. Pričakovali bi razvoj $\mathrm{v}$ smeri tako imenovanega preobrata matričnega jezika, vendar je proces prekinjen zaradi izredno hitrega jezikovnega premika od slovenščine k angleščini. Premik se izvrši v toku le treh generacij pri predvojnih priseljencih, pri povojnih pa še hitreje. Izrazito začasen in nestalen značaj slovenščine, ki se govori v tem okolju, nam onemogoča postuliranje strogih strukturalnih omejitev jezikovne rabe. Gre za specifično varianto slovenščine, ki zaradi možnega odkrivanja vpogledov $\mathrm{v}$ mehanizme jezikovnih sprememb nedvomno zasluži vso pozornost raziskovalcev tudi $\mathrm{v}$ prihodnje.

\section{Language Change in a Contact Situation: \\ The Case of Slovene in North America}

The article discusses the linguistic situation among immigrants of Slovene descent in the United States of America and Canada. Owing to the geographic distance between Slovenia and the host country and particularly to the very strong influence of the pragmatically dominant English, Slovene there is undergoing a very specific kind of development.

Data collected through empirical research (interview excerpts) are analyzed in order to identify contact-motivated changes of Slovene. These are encountered in all 
types of bilingual discourse (borrowing, code switching, English-influenced monolingual Slovene) and on different linguistic levels from phonology to semantics and pragmatics. The most salient areas of English linguistic impact, however, are morphology with its simplification, regularization and/or even deletion of Slovene inflectional system, and syntax with its gradual adoption of English-like SVO word order patterns.

On a sentence level these kinds of structures constitute what could be termed a composite matrix language, made up from the features of both languages. Development, though, stops short of the so-called matrix language turnover (MLT), because it is interrupted by a very rapid process of language shift from Slovene to English. This has been accomplished in the course of three generations in the case of pre-war immigrants and even faster in the case of post-war ones. The variety of Slovene in this particular context is therefore of a very temporary and unstable nature and defies the postulation of rigid structural constraints on it. It nevertheless represents a distinct contact variety of Slovene well worth further research because of the likely insights into the language change mechanisms that it may provide. 